\title{
The Effect of Connecting, Organizing, Reflecting, Extending Learning Model Assisted by Audio-Visual on Mathematics Learning Outcomes
}

\author{
Ni Kadek Veronika Dewi \\ Program Studi Pendidikan Guru Sekolah Dasar, Jurusan Pendidikan Dasar, Universitas Pendidikan Ganesha \\ Email:veronikadewi253@gmail.com
}

$\begin{array}{ll}\text { Ni Ketut Suarni } & \text { Kitum Studi Bimbingan Konseling, Jurusan Ilmu Pendidikan, Psikologi dan Bimbingan. Universitas Pendidikan Ganesha }\end{array}$ Email: niketut.suarni@undiksha.ac.id

I Gusti Ngurah Japa

Program Studi Pendidikan Guru Sekolah Dasar, Jurusan Pendidikan Dasar, Universitas Pendidikan Ganesha Email: igustingurah.japa@undiksha.ac.id

\section{A R T I C L E I N F O \\ Article history: \\ 1 Agustus 2020 Received in revised form \\ 20 September 2020 \\ Accepted 10 November 2020 \\ Available online 20 \\ November 2020 \\ Kata Kunci: \\ CORE, audio visual, hasil \\ belajar matematika}

\section{Keywords:}

CORE, audio visual,

matematics learning

outcomes

\begin{abstract}
A B S T R A K
Penelitian ini bertujuan untuk mengetahui pengaruh model pembelajaran Connecting, Organizing, Reflecting, Extending (CORE) berbantuan media audio visual terhadap hasil belajar matematika siswa kelas IV. Jenis penelitian yang digunakan adalah eksperimen semu (quasi eksperimen) dengan desain penelitian post-test only control group design. Populasi yang digunakan dalam penelitian ini adalah seluruh siswa kelas IV, dengan sampel yang digunakan yaitu kelas IVB dengan jumlah 34 orang siswa sebagai kelompok eksperimen dan kelas IVA dengan jumlah 36 orang siswa sebagai kelompok kontrol. Metode pengumpulan data yang digunakan adalah metode tes dengan jenis instrumen tes objektif pilihan ganda. Data yang diperoleh dianalisis menggunakan analisis statistik deskriptif dan analisis inferensial. Berdasarkan analisis uji-t diperoleh thitung $=21,547$ dan $\mathrm{t}_{\text {tabel }}=2,000$ dengan $\mathrm{db}=68$ pada taraf signifikansi $5 \%$. Dengan kriteria $\mathrm{t}_{\text {hitung }}>\mathrm{t}_{\text {tabel }}$ sehingga $\mathrm{H}_{0}$ ditolak dan $\mathrm{H}_{1}$ diterima. Dilihat dari perbedaan skor rata-rata antara kelompok eksperimen dan kelompok kontrol, ini menandakan bahwa terdapat pengaruh yang signifikan model pembelajaran CORE berbantuan media audio visual terhadap hasil belajar matematika siswa kelas IV
\end{abstract}

\begin{abstract}
A B S T R A C T
This study aims to determine the effect of the Connecting, Organizing, Reflecting, extending (CORE) learning model assisted with audio-visual media on fourth-grade students' mathematics learning outcomes. The type of research is a quasi-experimental research design with a post-test only control group design. The population used in this study was the fourth-grade, with the samples used were IVB class with 34 students as the experimental group and IVA class with 36 students as the control group. The data collection method used is a test method with multiple choice objective test instruments. The obtained data is analysed by using descriptive statistical analysis and inferential analysis. The analysis results obtained were the average score in the experimental group given with the treatment of the CORE learning model assisted by audio-visual media amounted to 21,91 . The control group that was not given the CORE learning model's treatment assisted by audio-visual media amounted to 14,00. The t-test analysis obtained $c_{\text {ount }} 21,547$ and $t_{\text {able }} 2,000$ with $\mathrm{db} .=68$ at a significance level of $5 \%$. With the criteria, $c_{\text {ount }}>t_{a b l e}$ so that $\mathrm{H}_{0}$ is rejected and $\mathrm{H}_{1}$ is accepted. The difference scores between the experimental and control groups indicate that there is a significant influence in applying the CORE learning model assisted with audio-visual media in the mathematics learning outcomes of fourth-grade students.
\end{abstract}

\section{Introduction}

Mathematics is a science as a means of thinking with structured logic. Elementary students find it difficult to understand mathematics well (Triningsih \& Mawardi, 2020). Mathematics is a subject that plays an important role in everyday life (Intan \& Hidayat, 2018). Mathematics is important because it is used to think for students in everyday life (Farib et al., 2019; Kahar, 2017; Nurfauziah et al., 2019). Mathematics learning must be more active in finding and building their knowledge. Learning mathematics requires technical assistance to convey material that requires complex understanding and concepts (Kurniawati \& Nita, 2018).

However, students sometimes in learning mathematics only stay silent when the teacher asks questions so that learning activities tend to be boring (Sabrina et al., 2017). Students have a mindset that does not like mathematics. It impacts students' interest and low learning motivation, so that their mathematics learning outcomes 
are also low (Thamrin et al., 2019). Mathematics is a subject that is considered the most difficult, the most boring. It often is also considered the most frightening subject (Arsana et al., 2019).

As an educator in learning mathematics, the teacher must understand the material presented (Anggoro, 2015). The teacher can do this through a learning process designed in various ways to be effective, active, and enjoyable. The objectives of learning mathematics will be achieved. As a teacher, educators must be able to make students active in the learning process. The active students in this learning will increase students' understanding, which will affect students' learning success. It is necessary to apply a learning process designed by applying a learning model to achieve optimal learning objectives. The learning model is very important in determining the learning success achieved by students. The learning model's function is a means to assist in the learning process (Usman \& Afriansyah, 2017). It can make it easier to understand learning. Students will also get different and memorable learning experiences through varied learning. Based on this, the application of an appropriate learning model will affect how the learning process will impact changes in student behavior both in terms of cognitive, affective and psychomotor as well as the level of understanding of students. The application of innovative learning models will affect the learning outcomes of students who will be achieved optimally.

However, in reality, learning mathematics in elementary schools still has many problems, based on the results of observations and interviews conducted in the fourth grade of SD Lab Undiksha Singaraja on October 28, 2019 and October 31, 2019. Mathematics learning in the learning process is still ongoing teacher-centered. Students in learning listen more to the teacher's explanations. It will affect students' condition in the class, such as students who are less focused on learning because they deliver more material with lectures. Students will feel bored learning, and students' attention will be diverted to something that is considered more interesting.

In addition to conventional learning, the teacher feels it is difficult to use the learning media used in the mathematics learning process to adjust the material to be given. So that this will affect the achievement of different learning outcomes, it is seen through students' scores during the mid-semester math test seen from 70 students, 30 students are in the sufficient category, 14 students are in a good category, and 24 students are in this very good category according to the assessment guide for elementary school. It indicates that students' mathematics learning outcomes have not been achieved optimally, with the range of scores obtained by students still far away. During the learning process, the teacher still uses a less varied learning design. It causes students to feel bored during the learning process quickly. It is necessary to apply a learning method or model to optimize students' learning outcomes, especially in mathematics, to overcome this problem.

Learning models that can overcome these problems is the Connecting, Organizing, Reflecting, Extending (CORE) learning model. (Hidayati \& Roesdiana, 2019; Konita \& Sugiarto, 2017). The CORE model (Connecting, Organizing, Reflecting, Extending) is a learning model based on constructivism theory that students must construct their knowledge through self-interaction with their environment. (Mardiana et al., 2020). The CORE learning model emphasizes students to think critically and be able to develop the information obtained. CORE is a learning model that emphasizes students' critical thinking skills in connecting, organizing, exploring, managing and developing the information obtained. So that students can take advantage or use their knowledge in the application of everyday life (Noka et al., 2019). The learning process by applying the Connecting, Organizing, Reflecting, Extending learning model through several learning steps: (1) opening lessons with activities that can attract students to learn, (2) delivering old concepts that have been previously obtained and linked to new concepts (Connecting), (3) organizing the ideas of students to understand a material (Organizing), (4) heterogeneous group division, (5) rethinking, exploring, and digging up information that has been obtained through group discussions (Reflecting), (6) developing, expanding, using, and discovering knowledge is done through individual assignments given by the teacher (Extending) (Prasetyo et al., 2018; Wardika et al., 2015). The advantages of the CORE learning model are: (1) students become more active, (2) train students to think critically, (3) students get memorable and meaningful learning experiences. By applying the CORE learning model, students will get a memorable learning experience, affecting student learning outcomes (Hidayati \& Roesdiana, 2019). The CORE learning model affects improving science learning outcomes (Beniasih et al., 2015).

The application of the Connecting, Organizing, Reflecting, Extending learning model in the learning process requires learning media as a support to achieve optimal learning objectives. Learning media are all tools and materials that can be used for educational purposes such as radio, television, books, newspapers, magazines and so on (Lestari et al., 2018). Learning media will make the learning atmosphere more attractive to increase student interest and motivation (Luawo \& Nugroho, 2018). One type of learning media that can be used is audiovisual media. Audio-visual media provides varied and non-monotonous lessons to develop and improve their understanding of learning independently (Yusantika et al., 2018). Audio-visual media has the following properties, namely the ability to increase perception, the ability to increase understanding, the ability to increase the transfer of learning, the ability to provide reinforcement or knowledge of the results achieved, and the ability to increase retention (memory) (Sutamin, 2019). Audio-visual media that displays the material's reality can provide real experiences to students when learning it to encourage self-activity (Agustini et al., 2016; Utami et al., 2019). Audio-visual media use to convey the teaching and learning process with more attractive media to increase children's interest in the learning process and convey the message is easier to accept and understand (Setiawan \& 
Bezaleel, 2019). Based on this description, it can be said that the presence of audio-visual media will have a positive impact on the learning process.

Through the application of the Connecting, Organizing, Reflecting, Extending learning model assisted by audio-visual media, students will become active, trained to think critically, connect, develop, explore, explore and reuse the information that has been obtained and the learning experiences obtained by students will be memorable and meaningful so that this will affect the achievement of optimal student learning outcomes. Based on the explanation above, research was conducted with the title "The Effect of Learning Model Connecting, Organizing, Reflecting, Extending Assisted by Audio Visual Media on Mathematics Learning Outcomes of Fourth Grade Students of SD Lab Undiksha Singaraja Academic Year 2019/2020". The purpose of this study is to analyze whether there is a significant influence on the learning model Connecting, Organizing, Reflecting, Extending assisted by audio-visual media on the fourth-grade mathematics learning outcomes of SD Lab Undiksha Singaraja for the 2019/2020 academic year.

\section{Method}

This research was conducted at SD Lab Undiksha Singaraja, Kecamatan Buleleng, Kebupaten Buleleng, where this research was carried out in the second semester of the 2019/2020 academic year. The study was conducted on each research sample, carried out from January to February 2020 with six treatments in the experimental and control groups. This type of research is a quasi-experimental research with a post-test only control group design.

This study's population was all fourth-grade students at SD Lab Undiksha Singaraja for the 2019/2020 school year. With the number of fourth grades in SD Lab Undiksha Singaraja, there are two classes: class IVA and class IVB with 70 students. The equivalence test of the students' midterm test learning outcomes was first carried out using the one-way ANAVA test to determine fourth-grade students' ability. The results obtained based on the equivalence test showed no significant difference in students' midterm test results. Sampling in this study using purposive sampling technique with certain considerations. (Syadeli, 2013) purposive sampling is a sampling technique before finally taking the research sample. So it is obtained that the IVB class at SD Lab Undiksha Singaraja is an experimental class with 34 students. Class IVA at SD Lab Undiksha Singaraja is a control class with a total of 36 students. By providing treatment with the learning model Connecting, Organizing, Reflecting, Extending assisted by audio-visual media in the experimental class and not giving treatment for the Connecting, Organizing, Reflecting, Extending learning model assisted by audio-visual media in the control class.

The procedure in this study consisted of several stages, including the preparation stage carried out by the researcher, namely: (1) carrying a cover letter to carry out observations to the school where the research was carried out, (2) carrying out initial observations to the school where the research was carried out and interviewing the fourth-grade teacher, (3) carry out data collection on learning outcomes as a benchmark in the implementation of experimental research, (4) carry out an equality test of the research population, (5) determine the research sample, (6) compile a learning design adapted to the steps of the CORE learning model, (7) ) preparing the learning media, namely audio-visual media, (8) arranging a grid of questions used for the post-test, (9) designing questions for the learning outcome test after being given treatment. The researcher carried out the experimental implementation stage by giving the learning model of Connecting, Organizing, Reflecting, and Extending assisted by audio-visual media in the experimental group. Whereas the control group was not given treatment, the two groups' treatment was given six meetings. It was giving the final post-test to both groups. The experiment's final stage carried out data analysis to prove the hypothesis formulated regarding the effect of the Connecting, Organizing, Reflecting, Extending learning model assisted by audio-visual media on mathematics learning outcomes.

The data collected in this study are mathematics learning outcomes. The method used to collect data is the test method with multiple-choice instruments. Multiple-choice tests are used to measure students' understanding of competence, especially in the cognitive domain. In the cognitive domain, there are six aspects of assessment including, C1 (understanding), C2 (knowledge), C3 (application), C4 (analysis), C5 (evaluation), and C6 (creating). The multiple-choice test used needs to be done with an instrument test first which includes, the content validity test is carried out by experts who are experts in their fields, based on the results of the assessment of all questions accepted by the two experts with the calculation of the content validity score obtained by 1.00 , meaning the mathematics learning result included in the criteria for content validity coefficient is very high. While testing the validity of test items assisted by Micrososft Excel 2016, the results obtained were 5 invalid test items and 25 test items that were declared valid.

Based on the results of the test reliability tests assisted by Microsoft Excel 2016, a reliability coefficient of 0.79 was obtained, indicating that the reliability of the mathematics learning outcomes test was high. The test of difference in test with Microsoft Excel 2016's help obtained nine very good quality test items, 13 good quality test items, and 3 fairly good quality test items. While the test for the difference in power of the test equipment obtained a result of 0.60 , the test equipment difference was classified as good. Microsoft Excel 2016 used to test the difficulty level. 14 test items have an easy difficulty level, 9 test items with a moderate difficulty level, and 2 
test items with a difficult difficulty level. While the test for the level of difficulty of the test kits obtained a result of 0.67, the mathematics learning achievement test equipment's difficulty level was classified as moderate. After the post-test data on mathematics learning outcomes were collected, the data were analyzed using descriptive statistics and inferential statistics. (Coleman \& Fuoss, 1955) states that descriptive statistics are statistics that serve to provide a description or description of the object of research, which is obtained through sample data or the research population to conclude. Descriptive statistics are used to describe mathematics learning outcomes in the experimental group and the control group, including mean, median, mode, standard deviation, and variance.

The next analysis was conducted, namely inferential statistical analysis. Inferential statistical analysis is an analytical technique used to analyze sample data from the population. Later results from the analysis will be generalized to the population where the sample comes from (Sirait, 2016). Inferential statistics used before carrying out the hypothesis test, the assumption test is carried out including the normality test of the data distribution with the chi-square formula and the variance homogeneity test with the F-test. Furthermore, the hypothesis test is carried out with the t-test.

\section{Result and Discussion}

The data that has been collected from the experimental group and the control group were analyzed. In the experimental group in class IVB, 34 students, after being given the post-test, the highest score was 24 , and the lowest score was 19. For the post-test descriptive statistical analysis summary results, the experimental group is presented in Table 1.

Table 2. Data Description of Experiment Group and Control Group

\begin{tabular}{llcc}
\hline No & Component & Experiment Group & Control Group \\
\hline 1 & Mean & 21,91 & 14,00 \\
2 & Median & 22,17 & 13,58 \\
3 & Mode & 22,83 & 13,08 \\
4 & Varians & 2,10 & 2,29 \\
5 & Satndard Deviation & 1,48 & 1,51 \\
\hline
\end{tabular}

Based on table 1, there is a difference between the control group's learning outcomes and the experimental group. This is indicated by the mean score of 21.91 (experimental class), 14.00 (control class), median score 22.17 (experimental class), 13, 58 (control class), Mode 22.83 (experimental class), 13.08 (control class). Based on these results, it can be concluded that there is a difference between the group that was taught using the CORE learning model using audio-visual media and students who were not taught with the CORE learning model using audiovisual media. The next analysis was carried out by testing the prerequisite data analysis before the hypothesis test analysis. The prerequisite test includes normality test and homogeneity test. The normality test aims to determine whether the data that has been obtained is normally distributed. The post-test results of the experimental group $\mathrm{X}^{2}{ }_{\text {hitung }}=2.530$ at the $5 \%$ significance level with $\mathrm{dk}=3$ obtained the results of $\mathrm{X}^{2}$ table $=7.815$ with $\mathrm{X}^{2}$ hitung $<\mathrm{X}^{2}$ table. So it can be synthesized that the distribution of post-test data in the experimental group is distributed "Normal". Whereas in the control group, the post-test results obtained $\mathrm{X}_{\text {count }}^{2}=6.196$ at the $5 \%$ significance level with $\mathrm{dk}=$ 3 , the result is $\mathrm{X} 2$ table $=7.815$. Based on the results of these calculations $\mathrm{X}^{2}$ hitung $<\mathrm{X}_{\text {tabel }}$ so that the distribution of post-test data in the control group is distributed "Normal".

The variance homogeneity test is carried out to determine whether the data obtained is the same as the variances that have been obtained. Homogeneity test in both groups used the F-test. The results of the homogeneity test of variance obtained the results of $F_{\text {count }}(1.04)$ and then compared with the results of $F_{\text {table }}$ with db $b_{\text {numerator }}=34$ $1=33$ and $\mathrm{db}_{\text {penominator }}=36-1=35$ at the $5 \%$ significance level. Obtained $\mathrm{F}_{\text {table }}=1.80$, it shows that $\mathrm{F}_{\text {count }}(1.04)$ $<\mathrm{F}_{\text {table }}(1.80)$ based on the results of these calculations the post-test score of mathematics learning outcomes in the experimental group and the control group has a variance "Homogeneous". After the normality test and homogeneity test were carried out, the hypothesis was tested using the independent sample t-test with the polled variance formula. The results of the calculation of the $t$ test, $t=21.547$ then compared with the $t$ table for $d b(n 1$ $+n 2-2)=34+36-2=68$ at the $5 \%$ significance level, the obtained $t_{\text {table }}=2,000$. So that $t_{\text {count }}>t_{\text {table }}(21.547>$ 2,000 ), because $\mathrm{t}$ count $>\mathrm{t}$ table then $\mathrm{H} 0$ is rejected and $\mathrm{H} 1$ is accepted so that the results are significant. Thus there is a significant influence on the learning model Connecting, Organizing, Reflecting, Extending assisted by audio visual media on the mathematics learning outcomes of fourth grade students of SD Lab Undiksha Singaraja for the 2019/2020 academic year. This is seen based on the difference in the post-test mean score obtained by the experimental group $(\mathrm{M}=21.91)$ and the control group $(\mathrm{M}=14.00)$.

The Connecting, Organizing, Reflecting, Extending (CORE) learning model assisted by audio-visual media on student mathematics learning outcomes is influenced by several things. Including students' activeness in learning will increase because students must always think critically in solving problems given by the teacher. 
Students' critical thinking power will be trained to solve the problems given. The learning that students get will be memorable and provide a different learning experience. In the learning process, the CORE learning model uses audio-visual learning media to deliver information to students. The use of this learning media will increase the memory of students. Students will be able to connect, organize, reflect, and develop or use their knowledge in everyday life. Learning models that can overcome these problems are Connecting, Organizing, Reflecting, Extending (CORE) learning model. (Hidayati \& Roesdiana, 2019; Konita \& Sugiarto, 2017). The CORE model (Connecting, Organizing, Reflecting, Extending) is a learning model based on constructivism theory. The students must construct their knowledge through self-interaction with their environment (Mardiana et al., 2020). The CORE learning model emphasizes students to think critically and be able to develop the information obtained. CORE is a learning model that emphasizes students' critical thinking skills in connecting, organizing, exploring, managing and developing the information obtained. So that students can take advantage or use their knowledge in the application of everyday life (Noka et al., 2019). The learning process by applying the Connecting, Organizing, Reflecting, Extending learning model through several learning steps, namely: (1) opening lessons with activities that can attract students to learn, (2) delivering old concepts that have been previously obtained and linked to new concepts (Connecting), (3) organizing the ideas of students to understand a material (Organizing), (4) heterogeneous group division, (5) rethinking, exploring, and digging up information that has been obtained through group discussions (Reflecting), (6) developing, expanding, using, and discovering knowledge is done through individual assignments given by the teacher (Extending) (Prasetyo et al., 2018; Wardika et al., 2015). The advantages of the CORE learning model are: (1) students become more active, (2) train students to think critically, (3) students get memorable and meaningful learning experiences. So that through the application of the CORE learning model, students will get a memorable learning experience, which will affect improving student learning outcomes according to (Hidayati \& Roesdiana, 2019). The CORE learning model affects improving science learning outcomes (Beniasih et al., 2015).

The application of the Connecting, Organizing, Reflecting, Extending learning model in the learning process requires learning media as a support to achieve optimal learning objectives. Learning media are all tools and materials that can be used for educational purposes such as radio, television, books, newspapers, magazines and so on (Lestari et al., 2018). Learning media will make the learning atmosphere more attractive to increase student interest and motivation (Luawo \& Nugroho, 2018). One type of learning media that can be used is audiovisual media. Audio-visual media provides varied and non-monotonous lessons to develop and improve their understanding of learning independently (Yusantika et al., 2018). Audio-visual media has the following properties, namely the ability to increase perception, the ability to increase understanding, the ability to increase the transfer of learning, the ability to provide reinforcement or knowledge of the results achieved, and the ability to increase retention (memory) (Sutamin, 2019). Audio-visual media that displays the reality of the material can provide real experiences to students when learning it to encourage self-activity (Agustini et al., 2016; Utami et al., 2019). Audio-visual media use to convey the teaching and learning process with more attractive media to increase children's interest in the learning process and convey the message is easier to accept and understand (Setiawan \& Bezaleel, 2019).

The Connecting, Organizing, Reflecting, Extending learning model assisted by audio-visual media applied to IVB grade students has increased students' activeness in learning, which affects optimal learning outcomes. Students dare to ask and answer questions given by the teacher actively. Students' memory is also growing, seen through when the teacher asks questions again about the learning material that has passed. Students remain enthusiastic in answering them. Students' critical thinking power is increasingly trained in solving a problem given by the teacher both individually and in groups. The learning process will also give a different impression to all students through audio-visual learning media so that students can develop and use their knowledge in everyday life. This opinion is in line with that expressed by Muizaddin and (Mardiana et al., 2020) stated that the CORE learning model consists of four learning stages, namely Connecting (connecting old information with new information), Organizing (organizing information or ideas obtained), Reflecting (thinking about and retrieving information that has been obtained), and Extending (expanding and using the knowledge that has been obtained). Research with the CORE learning model's application has also been supported by its success by previous research (Beniasih et al., 2015). The results of the study stated that the CORE learning model affected improving student science learning outcomes. Other research conducted by (Suta Widura, 2018) stated that the CORE learning model assisted by visual media affected improving student science learning outcomes.

Research that has been done regarding the application of the learning model Connecting, Organizing, Reflecting, Extending assisted by audio-visual media, mathematics learning outcomes in fourth-grade students of SD Lab Undiksha Singaraja Academic Year 2019/2020 has been optimally achieved. From the explanation above, it can be synthesized that there is a significant influence on the Connecting, Organizing, Reflecting, Extending (CORE) learning model assisted by audio-visual media on the mathematics learning outcomes fourth-grade students of SD Lab Undiksha Singaraja for the 2019/2020 academic year. Judging by the difference in the average score of post-test learning outcomes of students taught with the CORE learning model assisted by audio-visual media, with groups of students who are not taught using the CORE learning model assisted by audio-visual media. 


\section{Conclusion}

Based on data analysis from the results of learning mathematics in the experimental group with 34 students, the average score obtained was 21.91. In the control group with 36 students, the average score obtained was 14.00. It indicates that the experimental group's average score of learning outcomes is higher than the control group. Video conference Zoom Meeting. The results of the analysis of the hypothesis with the t-test on the acquisition of mathematics learning outcomes in the research sample obtained $t_{\text {count }}=21.547$ and $t_{\text {table }}=2,000$ for

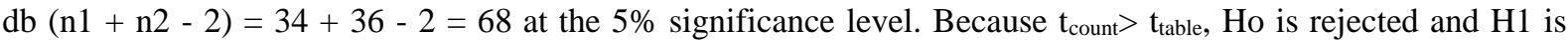
accepted. So it can be concluded that there is a significant influence on the learning model Connecting, Organizing, Reflecting, Extending assisted by audio-visual media on the mathematics learning outcomes at fourth-grade students of SD Lab Undiksha Singaraja for the 2019/2020 academic year.

\section{References}

Agustini, P. P., Kristiantari, M. . R., \& Putra, D. K. N. S. (2016). Penerapan Model Pembelajaran Berbasis Masalah Berbantuan Media Audio Visual Untuk Meningkatkan Hasil Belajar Keterampilan Menyimak Tema Sejarah Peradaban Indonesia Pada Siswa Kelas V Sdn 8 Sumerta. MIMBAR PGSD Undiksha, 4(1). https://doi.org/10.23887/jjpgsd.v4i1.7265

Anggoro, B. S. (2015). Pengembangan Modul Matematika Dengan Strategi Problem Solving untuk Mengukur Tingkat Kemampuan Berpikir Kreatif Matematis Siswa. Al-Jabar: Jurnal Pendidikan Matematika, 6(2), 121-129. https://doi.org/https://doi.org/10.24042/ajpm.v6i2.25

Beniasih, N. M. A., Suarjana, I. M., \& Rati, N. W. (2015). Pengaruh Model Pembelajaran Core Berbantuan Media Konkret terhadap Hasil Belajar IPA Siswa Kelas V SD. E-Journal PGSD Universitas Pendidikan Ganesha Jurusan, 3(1), 1-11.

Coleman, B. D., \& Fuoss, R. M. (1955). Quaternization Kinetics. I. Some Pyridine Derivatives in Tetramethylene Sulfone. Journal of the American Chemical Society, 77(21), 5472-5476. https://doi.org/10.1021/ja01626a006

Farib, P. M., Ikhsan, M., \& Subianto, M. (2019). Proses berpikir kritis matematis siswa sekolah menengah pertama melalui discovery learning. Jurnal Riset Pendidikan Matematika, 6(1), 99-117. https://doi.org/10.21831/jrpm.v6i1.21396

Hidayati, N., \& Roesdiana, L. (2019). Meningkatkan kemampuan koneksi matematik mahasiswa melalui model pembelajaran CORE dengan metode diskusi. Jurnal Penelitian Pendidikan Matematika Dan Pengajaran Matematika, 4(1), 31-34. https://doi.org/https://doi.org/10.37058/jp3m.v5i1.645

Intan, F., \& Hidayat, W. (2018). Hubungan Antara Keaktifan Belajar Siswa Terhadap Kemampuan Komunikasi Siswa SMK. Jurnal Visipena, 10(2), 1-15.

Kahar, M. S. (2017). Analisis Kemampuan Berpikir Matematis Siswa SMA kota Sorong terhadap Butir Soal dengan Graded Response Model. Tadris: Jurnal Keguruan Dan Ilmu Tarbiyah, 2(1), 11. https://doi.org/10.24042/tadris.v2i1.1389

Konita, M., \& Sugiarto, R. (2017). Analysis of Students Ability on Creative Thinking Aspects in terms of Cognitive Style in Mathematics Learning with CORE Model Using Constructivism Approach. Unnes Journal of Mathematics Education., 6(1), 63-70. https://doi.org/10.15294/ujme.v6i1.12496

Kurniawati, I. D., \& Nita, S. (2018). Media Pembelajaran Berbasis Multimedia Interaktif Untuk Meningkatkan Pemahaman Konsep Mahasiswa. DOUBLECLICK: Journal of Computer and Information Technology, 1(2), 68. https://doi.org/10.25273/doubleclick.v1i2.1540

Lestari, I. D., Halimatusha'diah, \& Puji Lestari, F. A. (2018). Penggunaan Media Audio, Visual, Audiovisual, dalam Meningkatkan Pembelajaran kepada Guru-guru. Jurnal PkM Pengabdian Kepada Masyarakat, 1(01), 55. https://doi.org/10.30998/jurnalpkm.v1i01.2361

Luawo, M. I. R., \& Nugroho, I. T. (2018). Media Komik untuk Mengembangkan Pemahaman Kemandirian Emosional Siswa Kelas XI SMA Negeri 111 Jakarta. INSIGHT: Jurnal Bimbingan Konseling, 7(2), 121132. https://doi.org/10.21009/insight.072.01

Mardiana, M., Deswita, H., \& Isharyadi, R. (2020). Pengaruh Model Pembelajaran CORE (Connecting, Organizing, Reflecting, Extending) Terhadap Kemampuan Koneksi Matematis Siswa Kelas VIII SMP N 3 Rambah. Jurnal Absis: Jurnal Pendidikan Matematika Dan Matematika, 2(2), 180-187. 
https://doi.org/10.30606/absis.v2i2.390

Noka, S. A. N., Said, H. B., \& Defitriani, E. (2019). Perbandingan Kemampuan Koneksi Matematis Siswa Melalui Model Pembelajaran Conecting Organizing Reflecting Extending (Core) Dengan Model Pembelajaran Konvensional Di Kelas Viii Smp Negeri 15 Kota Jambi. PHI: Jurnal Pendidikan Matematika, 3(1), 12. https://doi.org/10.33087/phi.v3i1.57

Nurfauziah, I., Nuryani, P., \& Fitriani, A. D. (2019). Penerapan Pendekatan RME Untuk Meningkatkan Hasil Belajar Siswa. Jurnal Pendidikan Guru Sekolah Dasar, 4(1), 388-397. https://ejournal.upi.edu/index.php/jpgsd/article/viewFile/20659/10385

Prasetyo, T. I., Syaban, M., \& Irmawan. (2018). Pengaruh Penerapan Model Pembelajaran Connecting, Organizing, Reflecting, Extending (CORE) Terhadap Peningkatan Kemampuan Koneksi Matematis Siswa SMA. Jurnal Pendidikan Dan Pembelajran Matematika, 3(1), 1-7. http://jurnal.fkip.unla.ac.id/index.php/intermathzo/article/view/279? articlesBySameAuthorPage=1

Sabrina, R., Fauzi, \& Yamin. (2017). Faktor-Faktor Penyebab Rendahnya Motivasi Belajar Siswa Dalam Proses Pembelajaran Matematika Di Kelas V Sd Negeri Garot Geuceu Aceh Besar. Jurnal Ilmiah Pendidikan Guru Sekolah Dasar, 2(4), 108-118. http://www.jim.unsyiah.ac.id/pgsd/article/download/7736/3350

Setiawan, A. D., \& Bezaleel, M. (2019). Perancangan Film Pendek "Bukan Hak-Ku” untuk Menanamkan Nilai Kejujuran pada Anak Usia 8-12 Tahun. ANDHARUPA: Jurnal Desain Komunikasi Visual \& Multimedia, 5(01), 127-140. https://doi.org/10.33633/andharupa.v5i01.1873

Sirait, E. D. (2016). Pengaruh Minat Belajar Terhadap Prestasi Belajar Matematika. Formatif: Jurnal Ilmiah Pendidikan MIPA, 6(1), 35-43. https://doi.org/10.30998/formatif.v6i1.750

Suta Widura, I. D. G. (2018). Pengaruh Model Core Berbantuan Media Visual Terhadap Hasil Belajar Ipa. Journal for Lesson and Learning Studies, 1(3), 258-267. https://doi.org/10.23887/jlls.v1i3.15390

Sutamin, N. W. (2019). Penggunaan Model Pembelajaran Small Group Work ( SGW ) Dengan Media Audio Visual Untuk Meningkatkan Prestasi Belajar Bahasa Indonesia. Jurnal Imiah Pendidikan Dan Pembelajaran, $3(2)$, 181-188. https://ejournal.undiksha.ac.id/index.php/JIPP/article/download/18075/10772

Syadeli, M. (2013). Struktur Kepemilikan, Profitabilitas Dan Ukuran Perusahaan Terhadap Kebijakan Hutang Perusahaan Pemanufakturan Di Bursa Efek Indonesia. Jurnal Manajemen Dan Akuntansi, 2, 79-94.

Thamrin, Y., Rusli, \& Bernard. (2019). Efektivitas Penerapan Model Kooperatif Tipe Example Non Example dalam Pembelajaran Matematika Siswa Kelas VII SMP. IMED, 3(1), 92-100.

Triningsih, R., \& Mawardi. (2020). Efektivitas Problem Based Learning dan Project Based Learning Ditinjau dari Keterampilan Berpikir Kritis Siswa. Jurnal Riset Pendidikan Dasar, 03(April), 51-56.

Usman, F. A., \& Afriansyah, E. A. (2017). Kemampuan Pemahaman Matematis Siswa Melalui Model Pembelajaran Auditory Intellectualy Repetition Dan Problem Based Learning (Studi Penelitian di SMP Negeri 1 CisurupanKelas VII). Jurnal Pendidikan Matematika, $11(1), \quad 68$. https://doi.org/http://dx.doi.org/10.22342/jpm.11.1.3890.67-78

Utami, M. T., Koeswati, H. D., \& Giarti, S. (2019). Model Problem Based Learning ( PBL ) Berbantuan Media audio Visual Untuk Meningkatkan Keteramoilan Berpikir Kritis Pada Siswa Kelas 5 Sekolah Dasar. MAJU, 6(1), 80-91. https://doi.org/https://www.ejournal.stkipbb

Wardika, W., Ariawan, U., \& Arsa, S. (2015). Penerapan Model CORE ( Connecting , Organizing, Reflecting, Extending ) Meningkatkan Hasil Aktivitas Belajar Perakitan Komputer Kelas XTKJ2. JPTE Universitas Pendidikan Ganesha Jurusan Pendidikan Teknik Elektro, 4(1), 1-10. https://doi.org/http://dx.doi.org/10.23887/jjpte.v6i3.20856

Yusantika, F. D., Suyitno, I., \& Furaidah. (2018). Pengaruh Media Audio dan Audio Visual terhadap Kemampuan Menyimak Siswa Kelas IV. Jurnal Pendidikan, 3(2), 251-258. https://doi.org/http://dx.doi.org/10.17977/jptpp.v3i2.10544 